\title{
Temperature Dependent of Mitotic Interval for Grass Puffer, Takifugu niphobles
}

\author{
Min Gyun Ko', Hyo Bin Lee', Hyun Woo Gil ${ }^{2}$, Shin Beom Kang ${ }^{3}{ }^{\dagger}$ In-Seok Park ${ }^{4}$, and Dong Soo Kim ${ }^{5}$ \\ ${ }^{I}$ Dept. of Fisheries Biology Center for Risk Assessment of Oceans and Fisheries Living Modified Organisms, \\ Pukyong National University, Busan 48513, Korea \\ ${ }^{2}$ Bio-Monitoring Center, Sejong 30121, Korea \\ ${ }^{3}$ Dept. of Ocean Physical Education, College of Ocean Science and Technology, Korea Maritime and Ocean University, \\ Busan 49112, Korea \\ ${ }^{4}$ Division of Marine Bioscience, College of Ocean Science and Technology, Korea Maritime and Ocean University, \\ Busan 49112, Korea \\ ${ }^{5}$ Dept. of Marine Bio-Materials \& Aquaculture, Pukyong National University, Busan 48513, Korea
}

\begin{abstract}
The objective of this study was to determine the mitotic intervals $\left(\tau_{0}\right)$ of two consecutive cell divisions and synchronous embryonic cleavage in grass puffer, Takifugu niphobles at different water temperatures $\left(18,20,22\right.$, and $\left.24^{\circ} \mathrm{C}\right)$. The color of the fertilized egg was light yellowish. The egg type was demersal and unadhesive. Egg weight was $0.09 \pm 0.002$ $\mathrm{mg}$. The sizes of unfertilized eggs were smaller than fertilized eggs in major axis and minor axis at $20^{\circ} \mathrm{C}(p<0.05)$. The size of the fertilized egg of $18^{\circ} \mathrm{C}$ water temperature group at the blastodisc stage was the smallest $(p<0.05)$, but no significant differences were observed in the other water temperatures group except $18^{\circ} \mathrm{C}$ water temperature group $(p>0.05)$. The first cleavage stages at $18,20,22$, and $24^{\circ} \mathrm{C}$ were at $75,90,105$, and 120 mins, respectively. As water temperature was increased, embryonic development and formation time of the first cleavage furrow were accelerated. There were negative correlation between $\tau_{0}$ and water temperature for grass puffer ( $\mathrm{Y}=-1.225 \mathrm{X}+70.05, R^{2}=0.988, n=10$, where $\mathrm{Y}$ was $\tau_{0}$ and $\mathrm{X}$ was temperature). This study confirmed that successful hatching of grass puffer was related to water temperature. Chromosome manipulation will be helpful for this species using cleavage frequency and $\tau_{0}$.
\end{abstract}

Key words : Mitotic intervals $\left(\tau_{0}\right)$, Water temperature, Grass puffer

\section{INTRODUCTION}

The grass puffer, Takifugu niphobles, is the most commonly found fish in adjacent seas of Korea. Grass puffer inhabits in coastal and brackish waters where sea water and fresh water are mixed with low salinity. They usually eat small crustaceans, shellfish, and cobwebds (Honma et al., 1980; Oh et al., 2000). Grass puffer exhibits unique spawning behaviors. It spawns in semilunar cycles from late spring (May) to summer (August). It will spawn to the intertidal zone and lay eggs in rock slits (Honma et al., 1980; Oh et al., 2000; Masaomi et al., 2013; Goo et al., 2015; Gil et al., 2017b). The grass puffer can grow up to $20 \mathrm{~cm}$. It is the smallest adult fish among Tetraodontidae

\footnotetext{
Manuscript received January 11, 2018, Received in revised form March 19, 2018, Accepted March 25, 2018

${ }^{\dagger}$ Corresponding Author : In-Seok Park, Division of Marine Bioscience, College of Ocean Science and Technology, Korea Maritime and Ocean University, Busan 49112, Korea. Tel: +82-51-410-4321, Fax: +82-51-404-4750, E-mail: ispark@kmou.ac.kr
}

This is an Open Access article distributed under the terms of the Creative Commons Attribution Non-Commercial License (http:// creative-commons.org/licenses/by-nc/3.0) which permits unrestricted non-commercial use, distribution, and reproduction in any medium, provided the original work is properly cited. 
fish (Nozaki et al., 1976; Oh et al., 2000). Because of its large population and small size, it is widely used as an ornamental fish. It is also possible to replace the expensive puffer fish dishes.

For grass puffer, anesthetic and physiological effects of clove oil and lidocaine- $\mathrm{HCl}$, effect of starvation, sexual dimorphism were previously studied (Gil et al., 2017a; Kim et al., 2017; Park, 2017). However, unlike previous studies, the objective of this study was to determine cleavage frequency and mitotic intervals of cell divisions in grass puffer at different water temperatures. Effective controls of the first cleavage and second ootid for chromosome manipulation in fish are dependent on the type and duration time of treatment. It is well known that the second meiosis is affected by water temperature, hydraulic pressure, and chemical treatment (Thorgaard et al., 1981; Thorgaard \& Allen, 1987; Ahn, 1995). Therefore, among different methods of fish breeding techniques, producing polyploidy, gynogenetic, and androgenetic diploid fish through chromosome manipulation is very important for the aquaculture industry (Thorgaard, 1983; Thorgaard \& Allen, 1987; Mims et al., 1997). Recently, Masaomi et al. (2013) have induced triploid grass puffer. Yoo et al. (2018) have also produced hybrids and hybrid triploids between river puffer and tiger puffer.

Among different techniques for chromosome manipulation, inhibiting the first cleavage and first or second polar body emission has been adapted to induce tetraploid or mitotic gynogenetic and androgenetic diploid (Mims et al., 1997; Masaomi et al., 2013). An appropriate Dettlaff unit is determined by the duration of one mitotic cycle during the time of synchronous cleavage divisions under different water temperatures. The Dettlaff unit is the duration in minutes of one mitotic cycle during early simultaneously embryonic beginning or the interval between two continuous cell divisions separation (Shelton, 1993; Saat \& Veersalu, 1996; Shelton et al., 1997). When measured over a range of temperatures, the relationship between mitotic intervals $\left(\tau_{0}\right)$ and temperature as determined by regression analysis can be used to predict developmental events that are influenced by temperature within a single species or between species with similar spawning biology (Dettlaff, 1986). Previous studies have been limited to egg development of grass puffer (Oh et al., 2000). Grass puffer is a very useful sample for fishery laboratory animals in physiological, hematological, and other experiments. Therefore, the objective of this study is to determine the mitotic intervals $\left(\tau_{0}\right)$ of two consecutive cell divisions and synchronous embryonic cleavage in grass puffer at different water temperatures $\left(18,20,22\right.$, and $\left.24^{\circ} \mathrm{C}\right)$.

\section{MATERIALS AND METHODS}

\section{Rearing condition and sampling}

Grass puffer, Takifugu niphobles, were collected from the harbor at Korea Maritime and Ocean University (KMOU), Busan, Korea, from May to August, 2016. Samples were transported to and reared in Fishery Genetics and Breeding Sciences Laboratory of the KMOU, Busan, Korea. Initial measurements of body weight (BW) and total length (TL) were made to the nearest $0.1 \mathrm{~g}$ and $0.1 \mathrm{~cm}$ using an electric balance (AX 200, Shimadzu Corp., Japan) and digital vernier calipers (CD-20 CP; Mitutoyo, Japan), respectively. The TL and BW of each species were $13.6 \pm 2.15 \mathrm{~cm}$ and $29.7 \pm 4.26 \mathrm{~g}$ in females and $12.7 \pm 2.53 \mathrm{~cm}$ and $26.5 \pm 3.29 \mathrm{~g}$ in males, respectively. Experimental samples were acclimated for one week in aquariums (200 L) with different water temperatures $\left(18,20,22\right.$, and $\left.24^{\circ} \mathrm{C}\right)$ to have sufficient adaptation.

\section{Egg collection and measurements}

We injected into the grass puffer 1,000 IU/g BW human chorionic gonadotropin (HCG, Sigma-Aldrich St. Louis, MO, USA). Twenty-four hours after the injection, eggs and sperm were extracted by pressing the abdomens. They were mixed in sufficient seawater by drying method. Ferti- 
lized eggs were adequately aerated and filtered in plastic sea water tank $(20 \mathrm{~L})$. Comparing the size of unfertilized eggs and fertilized eggs, unfertilized eggs were measured at $20^{\circ} \mathrm{C}$ while the fertilized eggs were divided into four different groups based on water temperature $(18,20,22$, and $24^{\circ} \mathrm{C}$ ). Color, type, weight, and size (major axis, minor axis, and extracellular matrix) of unfertilized and fertilized eggs (when blastodisc stage was developed) of grass puffers were compared. The weights of eggs were measured by weighing 10 eggs and dividing the number by 10 . The diameters of eggs were measured using the eyepiece micrometer of a microscope (Axioskop, Zeiss, Germany) under $50 \times$ magnification. Egg development was confirmed by sampling at intervals of 5 mins from $1 \mathrm{hr}$ after fertilization.

\section{Mitotic interval and first cleavage}

To investigate the period of the first cleavage of fertilized eggs depending on different temperatures also known as the Dettlaff unit (mitotic interval, $\tau_{0}$ ) of different cleavage frequencies and water temperatures, eggs were fertilized at $18,20,22$, and $24^{\circ} \mathrm{C}$ and sampled every 5 mins after fertilization. Each sample was fixed in $10 \%$ neutral formalin ( $100 \mathrm{~mL}$ formalin, $6.5 \mathrm{~g} \mathrm{Na}_{2} \mathrm{HPO}_{4} \cdot 12 \mathrm{H}_{2} \mathrm{O}, 4 \mathrm{~g}$ $\mathrm{KH}_{2} \mathrm{PO}_{4}$, fresh water $900 \mathrm{~mL}$ ) and kept at $4{ }^{\circ} \mathrm{C}$ until observation. $\tau_{0}$ was examined under microscope with $50 \times$ magnification. For $\tau_{0}$, the time it took for about $10 \%$ of the entire eggs to reach 2-cell stage $\left(\tau_{I}\right)$ and 8 -cell stage $\left(\tau_{\text {III }}\right)$ at each hatching temperature were measured according to the method of Ignat'eva (1975). Average $\tau_{0}$ was calculated by the formula $\tau_{0}=\left(\tau_{\mathrm{III}}-\tau_{\mathrm{I}}\right) / 2$. Linear regression analysis was performed to find the relationship between the average $\tau_{0}$ and water temperature. This experiment was performed in triplicates.

\section{Statistical analysis}

The relationship between the mean mitotic interval and water temperature was examined by simple linear regres- sion using SPSS Software (SPSS, Chicago, IL, USA).

\section{RESULTS AND DISCUSSION}

As shown in Table 1 and Fig. 1, egg color of grass puffer, Takifugu niphobles, is light yellowish. Egg type is unadhesive and demersal. Egg weight was measured at $0.09 \pm$ $0.002 \mathrm{mg}$ at water temperature of $20^{\circ} \mathrm{C}$. Among various puffer fish species, the eggs of grass puffer are light yellowish, unadhesive, and demersal with lots of oil globules (Oh et al., 2000). Regarding other puffer fish species, the eggs of tiger puffer (T. rubripes), river puffer (T. obscur$u s$ ), and panther puffer (T. pardalis) are opaque and milkywhite in color (Jang et al., 1996; Han, 1999; Han et al., 2001). The major axis of unfertilized egg was $1.05 \pm 0.041$ $\mathrm{mm}$. The minor axis of unfertilized egg was $1.01 \pm 0.038$ $\mathrm{mm}$. The extracellular matrix of unfertilized egg was $0.09 \pm 0.005 \mathrm{~mm}$. The sizes of fertilized eggs at four different water temperatures were significantly smaller than that of the other three groups in the long axis and short axis at $18^{\circ} \mathrm{C}$ and no significant difference was found in the other three groups $(p<0.05)$. The sizes of extracellular matrix showed no significant $(p>0.05)$ difference among four water temperature groups. When fertilized eggs were compared to unfertilized eggs at the same temperature of $20^{\circ} \mathrm{C}$, the major axis of fertilized egg was 1.36 times larger and the minor axis was 1.39 times larger $(p<0.05)$ than those of unfertilized eggs.

As shown in Fig. 2, egg development was accelerated when water temperature was increased from $18^{\circ} \mathrm{C}$ to $24^{\circ} \mathrm{C}$. Egg developmental rates of the four water temperature groups were similar to each other. However, the time that eggs reached the first cleavage was 30 mins at $18^{\circ} \mathrm{C}, 45$ mins at $20^{\circ} \mathrm{C}, 60 \mathrm{mins}$ at $22^{\circ} \mathrm{C}$, and 75 mins at $24^{\circ} \mathrm{C}$. After 90 mins, the first cleavage was finished in all water temperature groups. Oh et al. (2000) have reported the embryogenesis and early ontogenesis of a grass puffer. As mentioned by Oh et al. (2000), two-cell stage of grass puffer 
Table 1. Characteristics of unfertilized and fertilized eggs of grass puffer, Takifugu niphobles at different water temperatures*

\begin{tabular}{|c|c|c|c|c|c|}
\hline \multirow{2}{*}{$\begin{array}{c}\text { Characteristics } \\
\text { of egg }\end{array}$} & \multicolumn{2}{|c|}{ Color } & \multicolumn{3}{|c|}{ Type } \\
\hline & \multicolumn{2}{|c|}{ Light yellowish } & \multicolumn{3}{|c|}{ Unadhesive and demersal } \\
\hline Egg weight (mg) & \multicolumn{5}{|c|}{$0.09 \pm 0.002^{\mathrm{a}}$} \\
\hline \multicolumn{6}{|l|}{ Egg size (mm) } \\
\hline & & \multicolumn{4}{|c|}{ Water temperature for egg development $\left({ }^{\circ} \mathrm{C}\right)$} \\
\hline & & \multirow[t]{2}{*}{18} & 20 & 22 & \multirow[t]{2}{*}{24} \\
\hline \multirow{3}{*}{ Unfertilized egg } & Major axis & & \multicolumn{2}{|c|}{$1.05 \pm 0.041^{\mathrm{a}}$} & \\
\hline & Minor axis & & \multicolumn{2}{|c|}{$1.01 \pm 0.038^{\mathrm{a}}$} & \\
\hline & Extracellular matrix & & \multicolumn{2}{|c|}{$0.09 \pm 0.005^{\mathrm{a}}$} & \\
\hline \multirow{3}{*}{$\begin{array}{c}\text { Fertilized } \\
\text { egg }\end{array}$} & Major axis & $1.39 \pm 0.032^{\mathrm{a}}$ & $1.43 \pm 0.039^{\mathrm{b}}$ & $1.45 \pm 0.064^{\mathrm{b}}$ & $1.46 \pm 0.043^{\mathrm{b}}$ \\
\hline & Minor axis & $1.36 \pm 0.035^{\mathrm{a}}$ & $1.41 \pm 0.048^{b}$ & $1.42 \pm 0.053^{\mathrm{b}}$ & $1.43 \pm 0.052^{\mathrm{b}}$ \\
\hline & Extracellular matrix & $0.09 \pm 0.009^{a}$ & $0.09 \pm 0.005^{\mathrm{a}}$ & $0.11 \pm 0.009^{\mathrm{a}}$ & $0.09 \pm 0.008^{\mathrm{a}}$ \\
\hline
\end{tabular}

*Each value is presented as mean \pm SE of triplicated groups $(n=30)$. Means in rows with the different superscript letter are significantly different $(p<0.05)$. Fertilized egg sizes were measured for blastodisc stage at each water temperature.

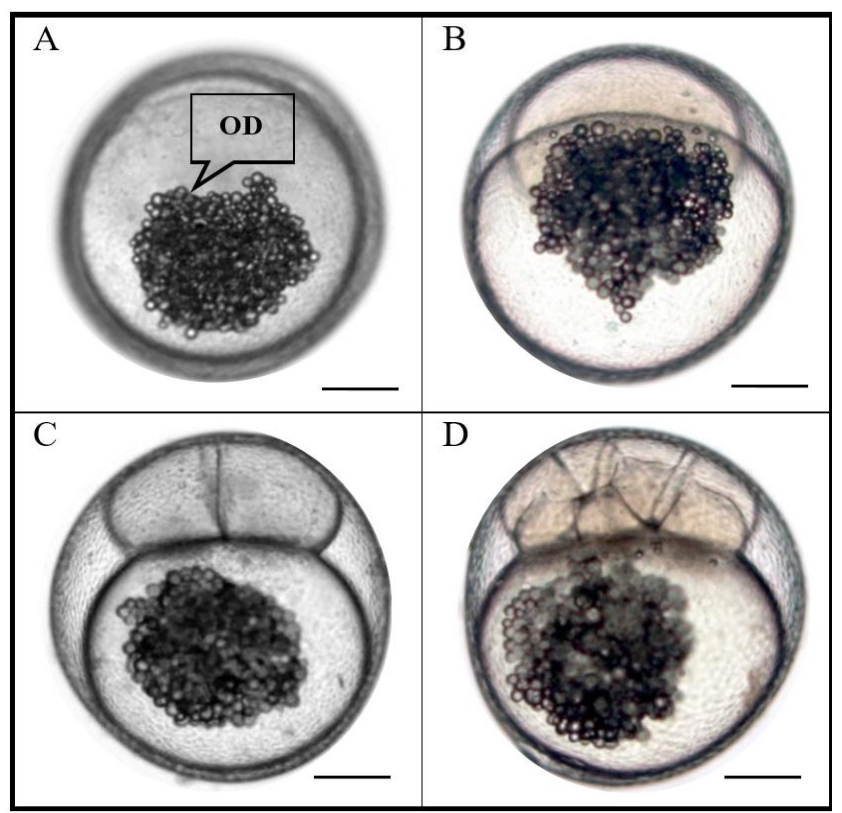

Fig. 1. Egg development of grass puffer, Takifugu niphobles. (A) Fertilezed egg, (B) Blastodisc stage, (C) 2-cell stage, and (D) 8-cell stage. Bars: $25 \mu \mathrm{m}$. OD: oil droplet.

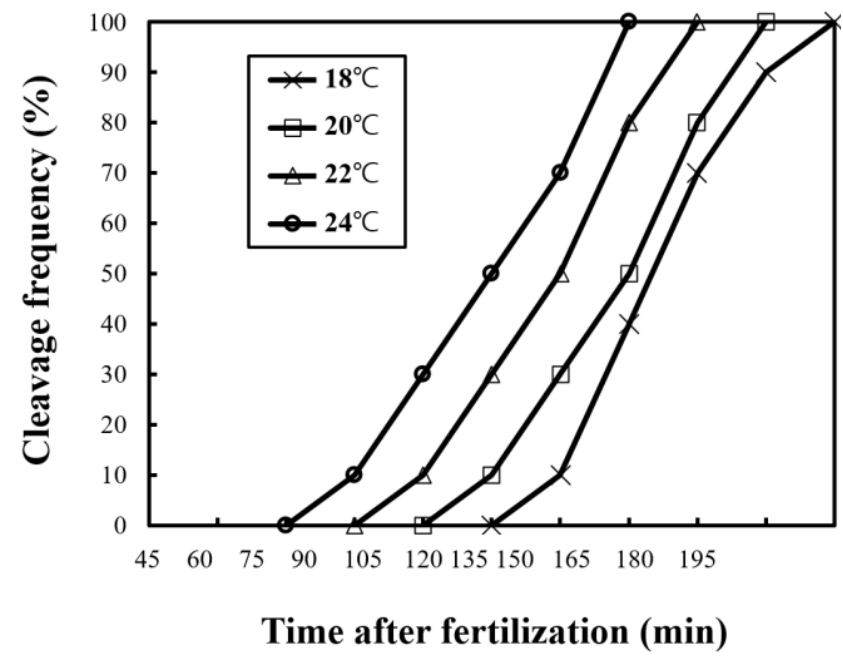

Fig. 2. The percentages of grass puffer, Takifugu niphobles, eggs developing to anaphase of the first cleavage at four different temperatures after fertilization.

egg can be reached within two hours after fertilization at $22^{\circ} \mathrm{C}$ and 8 -cell stage of egg can be reached at 4 hours 
after fertilization. Although our experimental water temperatures were different from those of Oh et al. (2000), the time needed to reach the 2-cell stage and the 8-cell stage at $18,20,22$, and $24^{\circ} \mathrm{C}$ was similar to that of Oh et al. (2000) at $20^{\circ} \mathrm{C}$. Egg development stage of tiger puffer is different from that of grass puffer. For example, the time needed to reach 2-cell stage and 8-cell stage has been reported to be 3:30 and 5:50 hours after fertilization, respectively (Han, 1999). Therefore, there is a time difference in egg development stage among different fish species or the same fish species at different temperatures. This could be used to identify the taxonomic ranges of different fish species. The eggs of grass puffer showed faster development at higher temperature (Fig. 2). As the water temperature was increased, the slope of the first cleavage frequency with elapsed time after fertilization was increased. Approximately $10 \%$ of fertilized eggs reached first cleavage frequency every $15 \mathrm{~min}$. These results are similar to those reported by Ignat'eva (1975), Saat \& Veersalu (1996), Park \& Im (2001), and Kim et al. (2011) showing that faster development has occurred at higher water temperature.

As shown in Fig. 3, the time of mitotic intervals $\left(\tau_{0}\right)$ was measured according to water temperature $(18,20,22$, and $24^{\circ} \mathrm{C}$ ). Unlike the tendency of cleavage frequency, $\tau_{0}$ was negatively correlated with water temperature $(\mathrm{Y}=-1.225 \mathrm{X}+$ $70.05, R^{2}=0.988$ where $\mathrm{Y}$ was $\tau_{0}$ and $\mathrm{X}$ was temperature). Of the four water temperature groups, $\tau_{0}$ was $53 \pm 1.9$ mins at $18^{\circ} \mathrm{C}, 49 \pm 2.3 \mathrm{mins}$ at $20^{\circ} \mathrm{C}, 45 \pm 1.7 \mathrm{mins}$ at $22^{\circ} \mathrm{C}$, and $40 \pm 1.8$ mins at $24^{\circ} \mathrm{C}$. The duration of one mitotic cycle during the period of identical cell divisions $\left(\tau_{0}\right)$ has proven to be an appropriate unit for comparing the duration of development processes at different temperatures in poikilothermic animals undergoing identical cell divisions during their early development (Shelton, 1993, 1997; Park \& Im, 2001; Kim et al., 2011). According to results shown in Fig. 3, we found that grass puffer showed faster development with decreased mitotic intervals when water temperature was increased, indicating a strong negative correlation

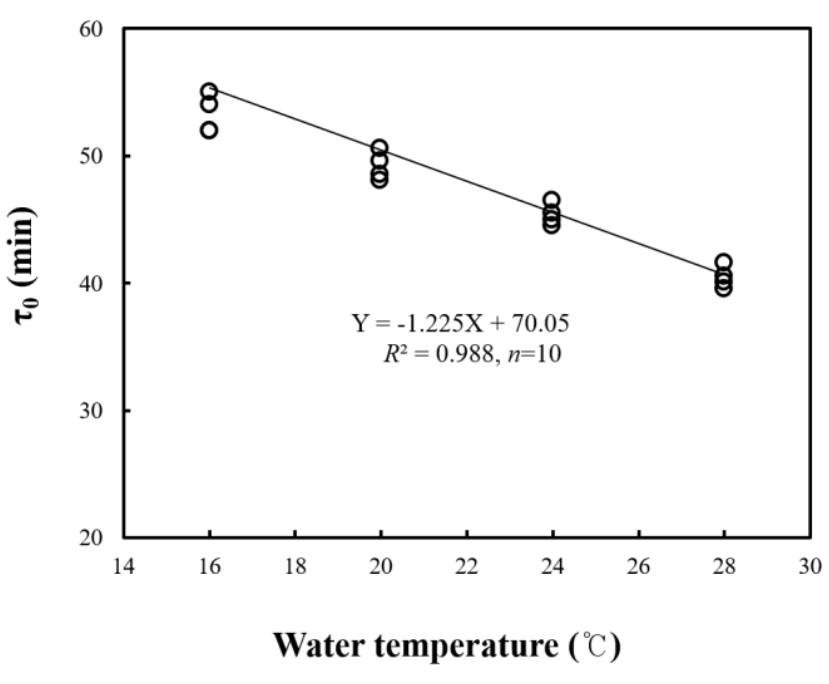

Fig. 3. Mitotic interval $\left(\tau_{0}, Y\right)$ of grass puffer, Takifugu niphobles, as function of temperature (X). Temperatures used are within normal range for spawning and early development for this species.

between $\tau_{0}$ and water temperature. Besides this study, similar results on the reduction of mitotic interval according to rising water temperature have been reported in far eastern catfish (Silurus asotus), black plaice (Pleuronectes obscurus), and Korean rose bitterling, Rhodeus uyekii (Park \& Im, 2001; Park and Im, 2010; Kim et al., 2011).

In summary, this study demonstrated obvious specific and clear differences in the time of the first cleavage and mitotic intervals at different temperatures in grass puffer. Data obtained from this study will add value to biological Takifugu species aquaculture database. This study will aid future investigations on seeding production by artificial fertilization, induction of triploid for producing sterile organisms, and induction of tetraploid, mitotic gynogenetic diploid, and androgenetic diploid grass puffer.

\section{ACKNOWLEDGEMENTS}

The comments of anonymous reviewers greatly improved the quality of this manuscript. We declare that all experiments in this study have complied with the current laws of Korea (Ordinance of Agriculture, Food and Fish- 
eries, No. 1, Regarding Experimental Animals, No. 9,932) and the ethic guideline of KMOU.

\section{REFERENCES}

Ahn CM (1995) Effects of photoperiod and water temperature on the reproductive cycle of the spring-spawning bitterling, Rhodeus uyekii (Pisces: Cyprinidae). Korean J Ichthyol 7:33-42.

Dettlaff TA (1986) The rate of development in poikilothermic animals calculated in astronomical and relative time units. J Therm Biol 11:1-7.

Gil HW, Lee TH, Choi CY, Kang CB, Park I-S (2017a) Anesthetic and physiological effects of clove oil and lidocaine- $\mathrm{HCl}$ on the grass puffer, Takifugu niphobles. Ocean Polar Res 39:1-11.

Gil HW, Lee TH, Choi CY, Kang CB, Park I-S (2017b) Induction of artificial spawning by human chorionic gonadotropin in the grass puffer, Takifugu niphobles. J Fish Mar Sci Edu 29:409-414.

Goo IB, Park I-S, Gil HW, Im JH (2015) Stimulation of spermiation by human chorionic gonadotropin and carp pituitary extract in grass puffer, Takifugu niphobles. Dev Reprod 19:253-258.

Han KH, Cho JK, Lee SH, Hwang DS, Yoo DJ (2001) Spawaning behavior and early life history of Takifugu pardalis (Teleostei: Tetraodontidae) in Korea. Kor J Ichthyol 3:181-189.

Han KN (1999) Development of eggs, larvae and juveniles of the puffer, Takifugu rubripes reared in the laboratory. Japan J Ichthyol 33:186-194.

Honma Y, Ozawa T, Chiba A (1980) Maturation and spawning behavior of the puffer, Fugu niphobles, occurring on the coast of Sado Island in the Sea of Japan (a preliminary report). Jpn J Ichthyol 27:129-138.

Ignat'eva GM (1975) Temperature dependence of cleavage rates in carp, pike, and whitefish. Sov J Dev Biol 5:2428.
Jang SI, Kang HW, Han HG (1996) Embryonic, larval and juvenile stages in yellow puffer, Takifugu obscurus. J Aquacult 1:11-18.

Kim B-S, Lim SG, Gil HW, Park I-S (2011) Temperature dependent index of mitotic interval $\left(\tau_{0}\right)$ for chromosome manipulation in Korean rose bitterling, Rhodeus uyekii. Fish Aquat Sci 14:429-433.

Kim DS, Gil HW, Lee TH, Park I-S (2017) Comparative analysis of sexual dimorphism between spawning season and non-spawning season in the grass puffer, $\mathrm{Ta}$ kifugu niphobles. J Fish Mar Sci Edu 29:447-452.

Masaomi H, Yutaka T, Kadoo M (2013) Gonadal development and fertility of triploid grass puffer, Takifugu niphobles induced by cold shock treatment. Mar Biotechnol 15:133-144.

Mims SD, Shelton WL, Linhart O, Wang C (1997) Induced meiotic gynogenesis of paddlefish, Polyodon spathula. J World Aquacult Soc 28:334-343.

Nozaki M, Tsutsumi T, Kobayashi H, Takei Y, Ichikawa T, Tsuneki K, Miyagawa K, Uemura H, Tatsumi Y (1976) Spawning habit of the puffer, Fugu niphobles (Jordanet et Snyder). Zool Mag 85:156-168.

Oh SH, Han KH, Kim YM, Joung HH, Shin SS, Kim YU (2000) Spawning behavior and early life history of grass puffer, Takifugu niphobles. Kor J Ichthyol 4:236-243.

Park I-S, Im S-Y (2010) Egg development and mitotic interval $\left(\tau_{0}\right)$ in black plaice, Pleuronectes obscurus (Herzenstein). Fish Aquat Sci 13:278-283.

Park I-S (2017) Effect of starvation on the just hatched grass puffer, Takifugu niphobles larvae. JMLS 2:27-33.

Park I-S, Im JH (2001) Determination of the temperature dependent index of mitotic interval $\left(\tau_{0}\right)$ for chromosome manipulation in far eastern catfish, Silurus asotus. Korean J Ichthyol 13:85-88.

Saat T, Veersalu A (1996) Duration of synchronous cleavage cycles and rate of development at different temperatures in the Baltic herring. J Fish Biol 48:658-663. Shelton WL (1993) Determination of the developmental 
duration $\left(\tau_{0}\right)$ for ploidy manipulation in carps. Isr J Aquacult 45:73-81.

Shelton WL, Mims SD, Clark JA, Hiott AE, Wang C (1997) A temperature-dependent index of mitotic interval $\left(\tau_{0}\right)$ for chromosome manipulation in paddlefish and shovelnose sturgeon. Prog Fish-Cult 59:229-234.

Thorgaard GH (1983) Chromosome set manipulation and sex control in fish. In: Fish Physiology. Vol. 9B. Hoar WS, Randall DJ and Donaldson EM, eds. Academic Press, New York, NY, pp 405-434.

Thorgaard GH, Allen SK Jr (1987) Chromosome manipu- lation and markers in fishery management. In: Population Genetics and Fishery Management. Ryman N and Utter F, eds. University of Washington Press, Seattle, WA, US, pp 319-331.

Thorgaard GH, Jazwin ME, Stier AR (1981) Polyploidy induced by heat shock in rainbow trout. Trans Amer Fish Soc 110:546-550.

Yoo GY, Lee TH, Gil HW, Lim SG, Park IS (2018) Cytogenetic analysis of hybrid and hybrid triploid between river puffer, Takifugu obscures and tiger puffer, T. rubripes. Aquacult Res 49:637-650. 